\title{
PENGARUH KEPEMIMPINAN STRATEJIK DAN MANAJEMEN PEMBIAYAAN TERHADAP MUTU PENDIDIKAN
}

\author{
Endi Rochaendi ${ }^{1}$, Aminudin $^{2}$, Eki Kiyamudin ${ }^{3}$, Andi Wahyudi ${ }^{4}$ \\ ${ }^{1,4}$ Program Studi Pendidikan Guru Sekolah Dasar, Universitas Alma Ata, Yogyakarta \\ J1. Brawijaya No.99, Kabupaten Bantul, Yogyakarta \\ ${ }^{2}$ Dinas Lingkungan Hidup, Kabupaten Majalengka \\ Jl. Gerakan Koperasi No.38, Kabupaten Majalengka \\ ${ }^{3}$ SMP Negeri 2 Panyingkiran, Kabupaten Majalengka \\ J1. Desa Jatiserang, Kabupaten Majalengka \\ Email: endi.rochaendi@almaata.ac.id
}

\begin{abstract}
This study aims to provide an overview of the extent of the influence of strategic leadership and financial management on the quality of junior high school education. The research approach used a descriptive method with a correlational quantitative approach. From the research results, three basic findinelmrgs were found: (1) strategic leadership has a significant influence on the quality of education by $43.5 \%$, (2), financial management has a significant effect on the quality of education by $32.6 \%$ and (3) strategic leadership and financing management provide a significant influence simultaneously and complement each other to increase the quality of education by $60.4 \%$. Thus, it is obtained a description that the strategic leadership and financial management factors have an impact and have a strong influence on improving the quality of education, especially in junior high school education units. The implication is that efforts to improve the quality of education do not always have to focus on issues of educational facilities and infrastructure, curriculum diversification, teacher quality or education budgets. Solving the problems mentioned above is indeed important, but it is also necessary to strengthen strategic leadership and financing management in educational units supported by a shared determination to implement it.
\end{abstract}

Keywords: Financing Management; Quality of Education and Strategic Leadership

\begin{abstract}
Abstrak: Penelitian ini ditujukan untuk memberikan gambaran mengenai sejauh mana pengaruh kepemimpinan strategik dan manajemen pembiayaan terhadap mutu pendidikan SMP. Pendekatan penelitian menggunakan metode deskriptif dengan memanfaatkan penelitian kuantitatif korelasional. Dari hasil penelitian didapatkan tiga temuan yang sangat mendasar, yaitu: (1) kepemimpinan strategik memiliki pengaruh yang signifikan terhadap mutu pendidikan sebesar 43,5 persen, (2), manajemen pembiayaan mempunyai pengaruh yang signifikan terhadap mutu pendidikan sebesar 32,6 persen dan (3) kepemimpinan strategik dan manajemen pembiayaan memberikan pengaruh signifikan secara bersamaan dan saling mengisi terhadap peningkatan mutu pendidikan sebesar 60,4 persen. Dengan demikian, diperoleh sebuah gambaran bahwa faktor kepemimpinan strategis dan manajemen pembiayaan berdampak dan memiliki pengaruh yang kuat terhadap peningkatan mutu pendidikan khususnya di satuan pendidikan SMP. Implikasinya, bahwa upaya peningkatan mutu pendidikan tidak selamanya harus berfokus pada permasalahan sarana dan prasarana pendidikan, diversifikasi kurikulum, mutu guru atau anggaran pendidikan. Penyelesaian masalah hal tersebut di atas memang penting, tetapi diperlukan juga penguatan kepemimpinan strategik dan manajemen pembiayaan di satuan pendidikan yang didukung oleh kebersamaan tekad untuk melaksanakannya.
\end{abstract}

Kata Kunci: Kepemimpinan Strategik; Manajemen Pembiayaan dan Mutu Pendidikan 
kenyataan menunjukkan bahwa derajat kualitas pendidikan Indonesia sampai saat ini belum sepenuhnya mencapai hasil yang menggembirakan. Hal ini terlihat dari rendahnya hasil pembelajaran dan munculnya disparitas akses pendidikan yang bersifat struktural. Berdasarkan data, prestasi siswa Indonesia selalu menempati posisi diurutan bawah karena penguasaan kemampuan akan mata pelajaran tertentu masih terbatas. Dari keseluruhan jumlah peserta didik pada jenjang pendidikan dasar dan menengah (Dikdasmen), hanya sebagian kecil yang mempunyai kemampuan tinggi dan kecakapan tingkat minimun dalam penguasaan sebuah mata pelajaran. Kurang lebih sepertiganya dari jumlah tersebut, hanya mencapai kemahiran tingkat dua dalam kemampuan membaca. Peserta didik yang memiliki kemampuan menterjemahkan dan mengelaborasi situasi dengan perhitungan matematika hanya mencapai sekitar 28 persen. Hasil studi PISA 2018 sebagaimana yang dilaporkan oleh UNDP (2019) mengungkapkan bahwa peringkat Indonesia belum banyak bergeser dari pemeringkatan PISA sebelumnya dan selalu berada di posisi urutan ke-10 dari bawah, seperti: (a) kemampuan membaca mencapai skor 379 dan berada pada urutan 73 dari 79 negara, (b) kemampuan matematika mencapai skor 371 dan berada pada urutan 74 dari 79 negara dan (c) kemampuan sains mencapai skor 396 dan berada pada urutan 71 dari 79 negara. Sementara itu skor rata-rata dunia untuk kemampuan membaca adalah 487, matematika adalah 489 dan sains adalah 498.

Sejalan dengan pernyataan di atas, survei Service Delivery Indicator menyatakan bahwa pada saat ini di Indonesia sedang terjadi krisis pembelajaran, yaitu terdapatnya sejumlah anak usia 15 tahun sebanyak 55 persen yang diprediksi masih buta huruf secara fungsional. Selanjutnya, rata-rata siswa Indonesia tertinggal satu setengah tahun dari tingkat pembelajaran di semua jenis sekolah dan hanya sekitar 28 persen dari seluruh jumlah siswa Indonesia yang baru mampu membaca setelah mereka menduduki kelas empat Sekolah Dasar (Sisdiyanto, 2021).

Permasalahan-permasalahan mengenai krisis pembelajaran diungkapkan oleh Kemendikbud (2021) dikarenakan beberapa hal, diantaranya : (a) pedagogi dan efektivitas para guru Indonesia masih perlu diperbaiki, (b) kurikulum pendidikan bersifat kaku, monoton, teoritis dan terfokus pada konten, (c) infrastruktur sekolah kurang memadai dan banyak yang rusak, dan (d) tata kelola pendidikan belum sepenuhnya mendukung proses pembelajaran.

Dalam upaya menuntaskan persoalan tersebut di atas, sangat diperlukan transformasi kepemimpinan kepala sekolah dan manajemen pembiayaan dalam rangka penguatan dan peningkatan kemampuan manajerial, kewirausahaan dan supervisi terhadap para guru dan tenaga kependidikan secara utuh dan kompleks (Fattah, 2000). Berdasarkan teorinya, pengembangan strategi melalui transformasi kepemimpinan kepala sekolah dan mekanisme pembiayaan pendidikan selain akan mengakibatkan terjadi peningkatan cakupan mutu dan efisiensi pengelolaan dan penyelenggaraan pendidikan. Juga memberikan peluang bagi penguatan akuntabilitas kepala satuan pendidikan dalam meningkatkan peran dan fungsinya sebagai pemimpin instruksional, pendamping bagi guru, serta dapat mendukung pembentukan komunitas pembelajar sekolah dan menjaga kinerja guru agar lebih efektif. Sehingga pada gilirannya dapat membuat manajemen sekolah lebih fokus dalam mewujudkan ekosistem pendidikan yang di dalamnya terdapat iklim sekolah dalam suasana yang lebih menyenangkan, keterbukaan, kemitraan para pemangku kepentingan pendidikan, dan keterlibatan aktif orang tua murid dan masyarakat.

Hasil penelitian sebelumnya mengenai kepemimpinan mengungkapkan bahwa penelitian mengenai pengenalan kepemimpinan lebih berisfat pada konteksnya saja dalam pengenalan kepemimpinan atau manajemen pembiayaan (Hamengkubuwono, 2021; Nopriyani, A., \& Hasanah, 2021). Penelitian kombinasi dari kepemimpinan strategik dan manajemen pembiayaan secara integratif belum banyak dielaborasi khususnya pada satuan pendidikan SMP. Untuk mengukur dan memahami seberapa jauh kombinasi integratif dari kedua konteks tersebut berpengaruh terhadap peningkatan mutu pendidikan di tingkat SMP, perlu adanya penelitian yang mampu memberikan telaahan yang lengkap dan kompleks sehingga dapat memberikan sumbangan pemikiran bagi peningkatan mutu pendidikan. Berdasarkan hal tersebut, dilaksanakan penelitian Pengaruh Kepemimpinan Strategik dan Manajemen Pembiayaan Terhadap Mutu Pendidikan SMP Negeri se-Kabupaten Majalengka. 


\section{METODE}

Penelitian ini memanpaatkan metodologi kuantitatif dengan pendekatan korelasional untuk menelaah hubungan asosiatif antara variabel bebas dengan variabel terikat (Sugiyono, 2013). Kegiatan penelitiannya didesign dengan menggunakan telaahan explanatory surveymethod guna menguji hipotesis dengan cara pengamatan atas dampak yang terjadi, kemudian setelah itu mencari faktor-faktor yang dimungkinkan menjadi penyebab melalui data-data tertentu. Riset yang dikembangkan adalah menelaah dua variabel bebas yaitu variabel kepemimpinan strategik dan variabel manajemen pembiayaan, dan satu variabel terikat yaitu variabel mutu pendidikan.

Penelitian ini dilakukan di Kabupaten Majalengka dengan subyek penelitiannya adalah sejumlah 69 SMP Negeri. Sehubungan cakupan area wilayah geografis dalam penelitian cukup luas, maka dalam pengambilan populasi penelitian dilaksanakan dalam beberapa langkah. Pertama, menentukan proporsi sekolah untuk dijadikan lokasi penelitian sebanyak 20 persen atau sebanyak 14 sekolah. Kedua, dengan menggunakan teknik area sampling kemudian membagi lokasi sekolah dalam tiga area wilayah yaitu utara, tengah dan selatan sebagaimana letak geografis sekolah. Setelah itu dilanjutkan dengan melakukan penetapan nama-nama sekolah yang akan menjadi lokasi penelitian. Ketiga, dalam pengambilan sample ditiap-tiap wilayah penelitian digunakan random sampling serta dalam penetapan sampel yang akan dijadikan sumber datanya memanpaatkan stratified random sampling dengan menggunakan persamaan finite population dari Weirs (Nazir, 2009). Dari pemanpaatan ragam metode itu akhirnya mendapatkan sebanyak 82 orang responden yang dijadikan sampel penelitian dari sejumlah populasi 542 orang guruguru,

Hasil penelitian ini didasarkan pada dua sumber data, yaitu data primer yang berasal dari rekaman hasil pengisian kuesioner laporan diri sendiri (self report) yang telah dijawab (diisi) secara tertutup oleh para responden. Berkaitan dengan kuesioner laporan diri, digunakan likerts summated rating dengan menyediakan lima alternatif jawaban yang diberikan pembobotan satu sampai lima (1-5). Sebelum disebar, kuesioner laporan diri tersebut diuji dengan berbagai instrumen pengujian seperti : (1) untuk mengukur tingkat kevalidan (uji validitas) digunakan korelasi product moment, (2) untuk mengukur konsistensi alat ukur dan kehandalan (uji reliabilitas) digunakan cronbach's alpha, (3) untuk mengetahui data yang dihubungkan sejenis (uji homogenitas) digunakan test of homogenity of variance, dan (4) untuk mengetahui pendistribusian data secara normal (uji normalitas) digunakan uji Kolmogorov-Smirnov.

Berkaitan dengan pengujian hipotesis, peneliti melaksanakan beberapa tahapan pengujian, yaitu: Pertama, melaksanakan pengujian signifikansi parameter invidual (uji t) dengan melaksanakan perbandingan antara nilai $t_{\text {hitung }}$ dengan nilai $t_{\text {tabel }}$, dengan ketentuan apabila nilai $t_{\text {hitung }} \geq t_{\text {tabel }}$ maka dianggap hipotesis tersebut signifikan, dan apabila $t_{\text {hitung }} \leq t_{\text {tabel }}$ maka dianggap hipotesis tersebut tidak signifikan. Kedua, melaksanakan pengujian signifikansi simultan (uji f) guna menentukan kondisi/sifat hipotesis. Ketiga, mengukur seberapa besar suatu variabel independen berpengaruh terhadap variabel dependen yang dinyatakan dalam pernyataan prosentase melalui pemanpaatan koofisien determinasi yang dinotasikan dengan hurup $\mathrm{p}^{2}$. Jika $\mathrm{p}^{2}$ semakin mendekati angka $100 \%$ maka pengaruh variabel bebas terhadap variabel terikat sangat kuat dan besar.

Dalam penelitian ini diajukan hipotesis penelitian (Hi), yaitu sebagai berikut: (a) ada pengaruh yang cukup signifikan kepemimpinan strategik terhadap mutu pendidikan di SMP Negeri se-Kabupaten Majalengka, (b) ada pengaruh yang signifikan manajemen pembiayaan terhadap mutu pendidikan di SMP Negeri se-Kabupaten Majalengka dan (c) ada pengaruh yang cukup signifikan kepemimpinan strategik dan manajemen pembiayaan terhadap mutu pendidikan di SMP Negeri se-Kabupaten Majalengka.

Sementara itu, variabel kepemimpinan strategik dibentuk oleh 4 indikator, yaitu kemampuan, kerja multi fungsi, konsiderasi dan kerangka manajerial berdasarkan referensi. Variabel manajemen pembiayaan dibentuk oleh 4 indikator, diantaranya perencanaan anggaran, mempersiapkan anggaran, mengelola pelaksanaan anggaran dan mengevaluasi pelaksanaan anggaran. Sedangkan variabel mutu pendidikan dibentuk juga oleh 4 indikator yaitu mutu input/struktur, mutu proses, mutu output dan mutu outcome. 


\section{HASIL DAN PEMBAHASAN}

\section{Pengujian Persyaratan Analisis}

Hasil pengujian persyaratan analisis memperlihatkan hasil-hasil sebagai berikut : Pertama, dari hasil penghitungan tingkat kevalidan (uji validitas) diketahui bahwa pertanyaan-pertanyaan yang disampaikan di kuesioner pada umumnya memiliki koefisien korelasi rata-rata di atas nilai 0,30 sehingga bisa diartikan bahwa alat ukur (kuesioner) penelitian tersebut memiliki tingkat validitas yang cukup tinggi (dinyatakan valid). Kedua, berdasarkan hasil uji reliabilitas dengan menggunakan cronbach's alpha didapatkan nilai $\mathrm{X}_{1}$ sebesar 0,902 , nilai $\mathrm{X}_{2}$ sebesar 0,885 dan nilai $\mathrm{Y}$ sebesar 0,897 , sehingga bisa diartikan bahwa instrumen penelitian tersebut memiliki tingkat koefisien reliabilitas yang tinggi serta mempunyai konsistensi interval (reliabilitas) yang memadai karena nilai yang didapatkan lebih besar dari angka 0,70. Dengan perkataan lain, hasil uji reliabilitas untuk semua variable memiliki $r_{\text {hitung }}>t_{\text {tabel }}$ dan nilai cronbach's alpha $>0,70$, sehingga bisa diartikan bahwa semua instrumen variabel tersebut dinyatakan realibel.

Ketiga, berkaitan dengan hasil uji normalitas menunjukkan bahwa : (a) untuk variabel Kepemimpinan Strategik $\left(\mathrm{X}_{1}\right)$ menghasilkan bahwa $\mathrm{Z}_{\text {hitung }}$ sebesar 1,198< $\mathrm{Z}_{\text {tabel }}(1,96)$ dan Asymptop Signifikansi 2-tailednya menghasilkan 0,113 lebih besar dari nilai kemaknaan $\alpha=0,05$ sehingga bisa diartikan bahwa data variabel Kepemimpinan Strategik berdistribusi normal, (b) untuk variable Manajemen Pembiayan $\left(\mathrm{X}_{2}\right)$ memperlihatkan bahwa $\mathrm{Z}_{\text {hitung }}$ sebesar $1,751<\mathrm{Z}_{\text {tabel }}(1,96)$ dan Asymptop Signifikansi 2-tailed menghasilkan 0,104 lebih besar dari nilai kemaknaan $\alpha=0,05$ sehingga bisa diartikan bahwa data variabel Manajemen Pembiayaan berdistribusi normal, dan (c) untuk variabel Mutu Pendidikan (Y) menunjukkan bahwa $Z_{\text {hitung }}$ sebesar 0,649 $<Z_{\text {tabel }}(1,96)$ dengan Asymptop Signifikansi 2-tailed menghasilkan 0,794 lebih besar dari nilai kemaknaan $\alpha=0,05$ maka dapat diartikan bahwa data variabel Mutu Pendidikan(Y) berdistribusi normal. Keempat, hasil Uji Homogenitas Varian menghasilkan sebagai berikut: (a) homogenitas Kepemimpinan Strategik ( $\mathrm{X}_{1}$ ) dengan Mutu Pendidikan (Y) mendapatkan nilai $\mathrm{F}_{\text {hitung }}$ sebesar 1,114 dan apabila dibandingkan dengan $\mathrm{F}_{\text {tabel }}$ sebesar 1,98 , maka hasil yang didapat adalah $\mathrm{F}_{\text {hitung }}<\mathrm{F}_{\text {tabel }}$ dengan nilai Asymptop Signifikansi 2-tailed yaitu $(0,000)<0,005$ adalah homogen, dengan demikian dapat diartikan bahwa Kepemimpinan Strategik dan Mutu Pendidikan bersifat homogen, dan (b) homogenitas Manajemen Pembiayaan $\left(\mathrm{X}_{2}\right)$ dengan Mutu Pendidikan (Y) menghasilkan $\mathrm{F}_{\text {hitung }}$ sebesar 1,370 dan apabila dibandingkan dengan $\mathrm{F}_{\text {tabel }}$ sebesar 1,98, maka hasil yang didapat $\mathrm{F}_{\text {hitung }}<\mathrm{F}_{\text {tabel }}$ dengan Asymptop Signifikansi 2-tailed $(0,000)<0,05$ adalah homogen, sehingga dapat diartikan bahwa Manajemen Pembiayaan dan Mutu Pendidikan bersifat homogen.

\section{Pengujian Hipotesis}

Pengujian hipotesis penelitian Pengaruh Kepemimpinan Strategik dan Manajemen Pembiayaan Terhadap Mutu Pendidikan SMP Negeri se-Kabupaten Majalengka, dari ketiga hipotesis yang diajukan secara keseluruhan menghasilkan penolakan Ho. Dengan perkataan lain, Hi dapat diterima.

Hasil pengujian hipotesis pertama mendapatkan bahwa arah koefisien korelasi (r) dalam tingkatan korelasi tinggi $(0,60<p \leq 0,80)$ dan nilai signifikansi $t_{\text {hitung }}$ lebih besar dari $t_{\text {tabel }}$ yang menunjukkan adanya pengaruh signifikan kepemimpinan strategik terhadap mutu pendidikan. Hasil tersebut didasarkan atas perhitungan yang dilakukan dengan bantuan SPSS 17,0 for windows melalui analisis korelasi parsial menghasilkan koefisien korelasi (r) positif sebesar 0,659 serta menghasilkan koefisien determinasi $\left(\mathrm{r}^{2}\right)$ sebesar 0,435 (43\%). Selanjutnya, hasil perhitungan tersebut di atas kemudian dikomparasikan dengan tabel Pearson Product Moment dan menghasilkan nilai sebesar 0,773. Hasil perhitungan lainnya menyatakan bahwa kepemimpinan strategik memiliki pengaruh yang signifikan terhadap mutu pendidikan berdasarkan perhitungan bahwa $\mathrm{t}_{\text {hitung }}>\mathrm{t}_{\text {tabel }}$ atau $\mathrm{t}(5,416)>\mathrm{t}(1,672)$ dengan $\mathrm{dk}=\mathrm{n}-2$. Dengan demikian dapat diartikan bahwa Ho ditolak dan Hi diterima, sehingga dapat dikatakan bahwa kepemimpinan strategik memiliki hubungan yang kuat terhadap mutu pendidikan.

Hasil pengujian hipotesis kedua menggambarkan bahwa arah koefisien korelasi (r) dalam tingkatan korelasi sedang $(0,40<\mathrm{p} \leq 0,60)$ dan nilai signifikansi $t_{\text {hitung }}$ lebih besar dari $t_{\text {tabel }}$ yang menunjukkan adanya pengaruh signifikan manajemen pembiayaan terhadap mutu pendidikan. Hasil tersebut didasarkan atas 
perhitungan yang dilakukan dengan bantuan SPSS 17,0 for windows melalui analisis korelasi parsial menghasilkan koefisien korelasi (r) positif sebesar 0,571 serta menghasilkan koefisien determinasi $\left(\mathrm{r}^{2}\right)$ sebesar 0,326 (32\%). Selanjutnya, hasil perhitungan tersebut di atas kemudian dikomparasikan dengan tabel Pearson Product Moment dan menghasilkan nilai sebesar 0,773. Hasil perhitungan lainnya menyatakan bahwa manajemen pembiayaan memiliki pengaruh yang signifikan terhadap mutu Pendidikan berdasarkan perhitungan bahwa $t_{\text {hitung }}>t_{\text {tabel }}$ atau $t(5,691)>t(1,672)$ dengan $d k=n-2$. Dengan demikian dapat diartikan bahwa Ho ditolak dan Hi diterima, sehingga dapat dikatakan bahwa manajemen pembiayaan memiliki hubungan yang cukup kuat terhadap mutu pendidikan.

Hasil pengujian hipotesis ketiga memperlihatkan bahwa arah koefisien korelasi (r) dalam tingkatan korelasi tinggi $(0,60<\mathrm{p} \leq 0,80)$ dan nilai signifikansi $\mathrm{t}_{\text {hitung }}$ lebih besar dari $\mathrm{t}_{\text {tabel }}$ yang menunjukkan adanya pengaruh signifikan kepemimpinan strategik dan manajemen pembiayaan terhadap mutu pendidikan. Hasil tersebut didasarkan atas perhitungan yang dilakukan dengan bantuan SPSS 17,0 for windows melalui analisis korelasi parsial menghasilkan koefisien korelasi (r) positif sebesar 0,777 serta menghasilkan koefisien determinasi $\left(\mathrm{r}^{2}\right)$ sebesar 0,604 (60\%). Selanjutnya, hasil perhitungan tersebut di atas kemudian dikomparasikan dengan tabel Pearson Product Moment dan menghasilkan nilai sebesar 0,777. Hasil perhitungan lainnya menyatakan bahwa kepemimpinan strategik dan manajemen pembiayaan memiliki pengaruh yang signifikan terhadap mutu pendidikan berdasarkan perhitungan bahwa $t_{\text {hitung }}>t_{\text {tabel }}$ atau $t$ $(4,596)>t(1,672)$ dengan $\mathrm{dk}=\mathrm{n}-2$. Dengan demikian dapat diartikan bahwa Ho ditolak dan Hi diterima, sehingga dapat dikatakan bahwa kepemimpinan strategik memiliki hubungan yang kuat terhadap mutu pendidikan.

Selain itu berdasarkan persamaan regresi berganda diketahui bahwa $Y=28,521+0,791+0,278$ dimana $b_{o}=28,521, b_{x 1}=0,791$ dan $b_{x 2}=0,278$, yang diartikan bahwa $Y$ adalah nilai ramalan mutu pendidikan dengan bilangan konstanta sebesar 28,521, nilai kepemimpinan strategik $\left(\mathrm{X}_{1}\right)$ adalah 0,791 dan nilai manajemen pembiayaan $\left(\mathrm{X}_{2}\right)$ sebesar 0,278. Perhitungan regresi berganda menghasilkan $\mathrm{X}_{1}$ $(0,791)>X_{2}(0,278)$ sehingga bisa diterjemahkan bahwa kepemimpinan strategik berkontribusi lebih besar terhadap mutu pendidikan apabila dibandingkan dengan manajemen pembiayaan.

Dari keseluruhan hasil pengujian hipotesis memberikan argumentasi bahwa kepemimpinan strategik $\left(\mathrm{X}_{1}\right)$ memberikan pengaruh sebesar $43,5 \%$ terhadap mutu pendidikan (Y) sementara sisanya sebesar $56,5 \%$ dimungkinkan dapat dipengaruhi oleh faktor lain. Sementara manajemen pembiayaan $\left(\mathrm{X}_{2}\right)$ juga memberikan pengaruh sebesar 32,6\% terhadap mutu pendidikan (Y) dan sisanya sebesar 67,4\% kemungkinan pula dipengaruhi oleh faktor lain. Kepemimpinan strategik dan manajemen pembiayaan secara bersama-sama dan saling mengisi (kombinasi) memberikan pengaruh sebesar 60,4\% terhadap mutu pendidikan dan sedangkan sisanya bisa dimungkinkan ada pengaruh dari faktor lain di luar penelitian ini. Berkaitan dengan faktor-faktor lainnya yang memiliki pengaruh terhadap mempengaruhi mutu pendidikan misalnya kebijakan pendidikan, manajemen pendidikan, kurikulum dan kegiatan pembelajaran, tingkat motivasi, kinerja dan budaya kerja guru dan tenaga kependidikan, iklim budaya dan lingkungan sekolah, keterlibatan dan kemitraan masyarakat, pengawasan dan supervisi pendidikan dan lain-lain. Cerminan dari pengaruh kepemimpinan strategik dan manajemen pembiayaan terhadap mutu pendidikan dapat digambarkan sebagai berikut:

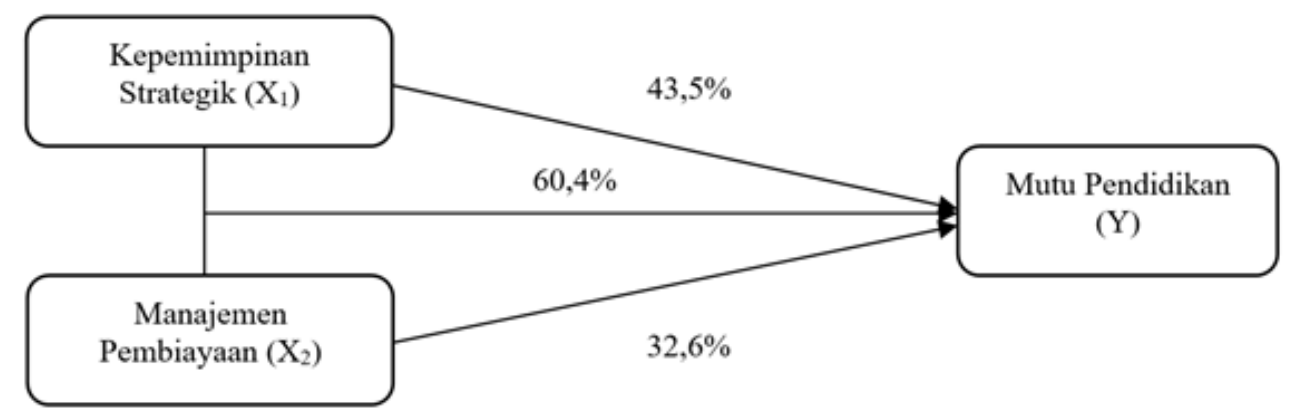

Gambar 1. Derajat Pengaruh Kepemimpinan Strategik dan Manajemen Pembiayaan Terhadap Mutu Pendidikan 


\section{Pengaruh Kepemimpinan Strategik terhadap Mutu Pendidikan}

Faktor kepemimpinan sangat berpengaruh terhadap peningkatan mutu pendidikan. Sebagaimana hasil penelitian menunjukkan bahwa pengaruh kepemimpinan strategik terhadap mutu pendidikan menghasilkan nilai koefisien korelasi sebesar 0,659 atau sebesar 43,5 persen. Hal ini berarti, lebih kurang dari separuhnya upaya peningkatan mutu pendidikan sangat dipengaruhi oleh aspek kepemimpinan. Pernyataan tersebut bersebadan dengan hasil penelitian OECD tahun 2008, dikatakan bahwa kepemimpinan dapat meningkatkan prestasi satuan pendidikan dan peserta didik melalui peningkatan motivasi dan kapasitas guru, pengembangan iklim budaya dan lingkungan sekolah serta peningkatan efisiensi pengelolaan dan penyelenggaraan proses pembelajaran dan pendidikan. Kepemimpinan sekolah telah menjadi prioritas dalam agenda kebijakan pendidikan internasional. Kepemimpinan memainkan peran kunci dalam meningkatkan hasil sekolah dengan mempengaruhi motivasi dan kapasitas guru, serta iklim dan lingkungan sekolah. Kepemimpinan sekolah yang efektif sangat penting untuk meningkatkan efisiensi dan pemerataan sekolah (Pont, Nusche, \& Moorman, 2008)

Di samping itu, hasil penelitian lainnya menggambarkan bahwa kepemimpinan pendidikan menjadi fungsi penting dalam mengembangkan kapasitas satuan pendidikan untuk dapat bekerja lebih efektif dan melakukan berbagai reformasi dalam pengembangan guru-guru, menciptakan iklim dan lingkungan pembelajaran (Elmore, 2018). Pada sisi ini, bisa dikatakan pula bahwa peran kepemimpinan adalah memastikan bahwa peserta didik dan para pendidik bisa tetap belajar, berkembang dan melakukan adaptasi dengan iklim dan lingkungan pembelajaran (Stoll, Bolam, Mc. Mahon, \& Wallace, 2006). Kepemimpinan paling tidak memiliki beberapa nilai strategis dalam mengembangkan sumber-sumber daya baru, menegakkan akuntabilitas dan memperluas prioritas anggaran dan instruksional pada satuan pendidikan. Penemuan ini menguatkan fakta bahwa kepemimpinan adalah faktor penting bagi keberhasilan peningkatan mutu pendidikan. Faktor kepemimpinan fokus pada upaya meningkatkan praktik kelas, kebijakan sekolah, dan hubungan antara masing-masing sekolah dan dunia luar (Pont et al., 2008). Hasil penelitian The Wallace Foundation (2012) lebih jauh menunjukkan bahwa terdapat hubungan empiris antara kepemimpinan sekolah dengan peningkatan prestasi siswa (mutu pendidikan). Dalam konteks tersebut, dikatakan bahwa sebagian besar variabel sekolah yang dipertimbangkan secara terpisah memiliki pengaruh paling kecil terhadap pembelajaran (Wahyudi et al, 2019)

Konsepsi tentang kepemimpinan tersebut di atas bisa dipahami sebagai kepemimpinan strategis, yaitu kemampuan untuk mempengaruhi, menggerakan dan memotivasi individual lain melalui kegiatan pemberdayaan dan penguatan satuan organisasi dalam upaya meningkatkan pencapaian organisasi termasuk di dalamnya menjaga stabilitas anggaran keuangan. Makna yang terkandung dalam kepemimpinan strategis adalah daya dorong yang dilakukan, tujuan yang harus dicapai secara efektif dan produktif serta tingkat fleksibilitas dalam tata kelola. Deskripsi tersebut di atas menjadikan kepemimpinan strategis sebagai kemampuan untuk melaksanakan antisipasi, mengembangkan dan meningkatkan fleksibilitas dan memberdayakan orang lain untuk melakukan perubahan strategi yang diperlukan (Sachin \& Bansidhar, 2013). Atau penciptaan keunggulan bersaing yang dilaksanakan oleh manajemen untuk melaksanakan tata kelola dengan memanpaatkan hal-hal yang bersifat strategis (Hill \& Jones, 2013). Dengan perkataan lain kepemimpinan strategis adalah koherensi, responsibiliti, adaptasi dan implementasi yang strategis.

Pemahaman tentang kepemimpinan strategis akan mengarah kepada kapasitas yang melekat di dalamnya, yaitu (a) mempunyai kejelasan visi dan misi dan complicated, kemudian disosialisasikan kepada berbagai pemangku kepentingan serta dimplementasikan secara konsisten dan konsekuen dalam berbagai aktifitas untuk melakukan perubahan dan peningkatan satuan organisasi, (b) mengelaborasi model-model pencapaian tujuan yang efektif, efisien dan produktif, (c) berintegritas dan mempunyai sikap komitmen yang luas dalam berbagai sikap, perilaku dan tindakan, (d) memberdayakan jaringan informasi dan komunikasi yang seimbang, terarah dan transparan, (e) distributif dan delegatif dalam pemberdayaan tanggung jawab dan kewenangan, (f) cerdas dalam mengaktualisasikan program dan kegiatan serta (g) adaptif dan memiliki daya tahan emosional yang cukup tinggi dalam menghadapi berbagai persoalan. 
Kepemimpinan strategis sebagai tersebut di atas dipandang dapat meningkatkan mutu pendidikan. Pola kepemimpinannya mengembangkan satuan pendidikan dan kegiatan proses belajar mengajar sebagai kunci untuk peningkatan mutu pendidikan. Signifikansi pelaksanaan tugasnya tidak fokus pada regulasi yang dikembangkan tetapi mengembangkan diskresi dan inisiasi serta merespons halhal yang berkembang di lingkungan satuan pendidikannya. Makna kepemimpinanannya bukan hanya melaksanakan apa yang sudah tersedia, tetapi juga mengandung makna melaksanakan lingkup manajerial yang diperluas. Dalam posisi seperti itu, maka koeksistensi dari kepemimpinan strategis tersebut dalam peningkatan mutu pendidikan adalah membangun komitmen dan konsekuensi untuk melakukan beberapa tindakan, seperti : (a) menjadikan visi dan misi satuan pendidikan sebagai landasan pijakan untuk bersikap dan bertindak, (b) memelihara dan menjaga budaya kerja yang positif dan prestatif, (c) mempunyai standar operasional prosedur (SOP) yang berkeadilan untuk menyelesaikan masalah dan memberikan penghargaan, (d) mengembangkan komunikasi yang kondusif dan dialogis, (e) mengembangkan koherensial pada sistem dan kelembagaan untuk saling berbagi, membangun kesamaan nilai dan saling mendukung, (f) memperkaya dan memberdayakan sikap positif, wawasan dan pengetahuan serta kemampuan dan kecakapan dalam sebuah komunitas kelembagaan serta (g) memberikan keteladanan dan praktik-praktik baik. Dengan demikian dalam ukuran peningkatan mutu pendidikan, kepemimpinan strategis tersebut akan berpangkal pada komitmen, pengembangan strategi, bimbingan teknis dan pengambilan keputusan.

Hal tersebut sejalan dengan pernyataan bahwa kepemimpinan strategik adalah kepemimpinan yang mampu menjadikan nilai-nilai sebagai landasan berpikir untuk melakukan perubahan-perubahan dan menginisiasi perubahan tersebut ke arah kemajuan. Formulasi konsep kepemimpinan strategik tersebut sangat menjanjikan dalam tata kelola pendidikan di masa depan supaya : (1) tidak menunggu, yaitu bahwa para para pengelola dan penyelenggara satuan pendidikan harus memiliki keaktifan dan memperoleh keuntungan di awal kegiatan; (2) memiliki karakter yang berkualitas dan kredibel; (3) pengelola dan penyelenggara satuan pendidikan di samping memiliki kejelasan visi dan misi juga dapat memberikan pengayoman dan penghargaan; dan (4) memiliki komitmen dan konsekuen atas sikap, tindakan dan perbuatan. Di samping itu, secara bersama-sama para pengelola dan penyelenggara satuan pendidikan menjadi penyelaras untuk menguasahakan agar program-program kegiatan dapat terlaksana dengan sebagaimana mestinya. Katalisatornya adalah "kami" dan bukan "aku". Implikasinya, kepemimpinan strategis berkaitan dengan pencapaian visi dan misi, penciptaan suasana pelaksanaan pekerjaan yang sehat dan menyenangkan serta pengembangan peranan secara interpersonal, informasional dan pengambil keputusan. Pada sisi ini maka membutuhkan conception yang tepat, competency yang cukup, connection yang luas, dan confidence (Rochaendi, 2018).

\section{Pengaruh Manajemen Pembiayaan terhadap Mutu Pendidikan}

Manajemen pembiayaan berperan penting dalam kegiatan pengelolaan dan penyelenggaraan pendidikan sehingga menjadi faktor pendukung dalam keberhasilan peningkatan mutu pendidikan. Pernyataan tersebut merupakan substansi dari hasil penelitian pengaruh manajemen pembiayaan terhadap mutu pendidikan. Dari hasil penelitian tersebut memperlihatkan bahwa pengaruh manajemen pembiayaan terhadap mutu pendidikan menghasilkan nilai koefisien korelasi sebesar 0,571 atau 32,6 persen. Sehingga bisa dikatakan bahwa manajemen pembiayaan pendidikan mempunya tingkat pengaruh dan kontribusi yang signifikan bagi peningkatan prestasi belajar peserta didik, disiplin dan presensi kehadiran pendidik dan tenaga kependidikan serta terciptanya iklim dan suasana pekerjaan yang menyenangkan dan bergairah (Fattah, 2000).

Manajemen pembiayaan di satuan pendidikan pada dasarnya adalah pengaturan kebijakan tata kelola anggaran pendidikan yang diberikan secara luas kepada sekolah. Dalam konteks tersebut terjadi perubahan struktur kewenangan sistem pengelolaan keuangan dengan melakukan pemberdayaan, pemberian wewenang dan pengembalian urusan pembiayaan pendidikan kepada satuan pendidikan.

Dalam pelaksanaannya terdapat tiga esensi dasar dalam manajemen pembiayaan, yaitu : Pertama, pengelolaan keuangan berpusat pada tingkat sekolah yang berbasis pada kebutuhan sekolah itu sendiri. Sekolah diberikan kebebasan sepenuhnya untuk mengelola pengaturan anggaran pendidikan di 
lingkungan masing-masing hingga terjadinya otonomi pendidikan yang benar-benar nyata. Ini artinya bahwa pengelolaan keuangan sekolah akan memberi peran aktif yang lebih luas para pemimpin sekolah dalam berbagai program peningkatan mutu pendidikan. Kedua, sekolah diharapkan mampu menggali dan mengembangkan sumber-sumber biaya yang ada di lingkungannya. Manajemen pembiayaan bisa diartikan sebagai kemampuan sekolah untuk membiayai dirinya sendiri, memperkecil ketergantungan terhadap bantuan-bantuan dari pemerintah/pemerintah daerah dan mampu membiayai dirinya sendiri. Strategi yang dikembangkan agar sekolah mampu melaksanakan manajemen pembiayaan melalui pertumbuhan dan pemerataan. Dalam strategi pertumbuhan diharapkan sekolah bisa bekerjasama dengan komite sekolah untuk melaksanakan pengelolaan aset-aset sekolah dengan melibatkan partisipasi masyarakat secara keseluruhan.

Sedangkan implementasi strategi kedua adalah menjadikan bantuan biaya operasional sekolah yang berasal dari pemerintah sebagai alat survive dan kekuatan sekolah untuk meningkatkan mutu pendidikan. Ketiga, dalam implementasi manajemen pembiayaan sekolah diberi kebebasan untuk berekpresi dalam mengembangkan penyelenggaraan pendidikan. Momentum dalam manajamen pembiayaan adalah penciptaan demokratisasi dan desentralisasi RAPBS/APB Sekolah yang disesuaikan dengan tingkat kebutuhan program pembelajaran di sekolah. Dalam skemanya diharapkan hirarki dalam pengambilan keputusan mengenai pembiayaan pendidikan diserahkan sepenuhnya kepada sekolah dengan kontrol dan supervisi dari komite sekolah.

Di sisi lain, manajemen pembiayaan dapat membuat profil komite sekolah yang bergairah dalam mendukung peningkatan mutu pendidikan dengan mengembangkan keleluasan peran dan fungsi komite sekolah sebagai perencanaan pembiayaan pendidikan di seekolah. Dalam kaitan itu, komite sekolah harus terlibat dan ikut serta secara penuh dalam perencanaan pengelolaan pendidikan di sekolah. Sehingga apa yang direncanakan sesuai dan selaras dengan kebutuhan sekolah dan masyarakat serta bertindak sebagai pendukung utama dalam penyediaan pembiayaan pendidikan. Disinilah peran manajemen pembiayaan untuk memberdayakan komite sekolah dan masyarakat dalam mewujudkan pendidikan yang lebih bermutu.

\section{Pengaruh Kepemimpinan Strategik dan Manajemen Pembiayaan terhadap Mutu Pendidikan}

Meningkat tidaknya mutu pendidikan banyak dipengaruhi oleh berbagai faktor. Hasil penelitian menunjukkan bahwa pengaruh kepemimpinan strategik dan manajemen pembiayaan mempunyai dampak pengaruh yang signifikan terhadap peningkatan mutu pendidikan, dengan nilai koefisien korelasi sebesar 0,777 atau 60,4 persen. Hasil penelitian itu tidak dapat dinafikan, sehubungan kepemimpinan dan pembiayaan memainkan peran kunci dalam meningkatkan keberhasilan pengelolaan dan penyelenggaraan pembelajaran dan pendidikan khususnya dalam peningkatan prestasi pendidikan dan pembelajaran, peran kunci dalam meningkatkan praktik kelas, kebijakan sekolah, dan hubungan antara masing-masing sekolah dan dunia luar (Pont et al., 2008).

Mutu pendidikan akan dapat meningkat dan menghasilkan prestasi yang berkualitas apabila didorong oleh kombinasi antara kepemimpinan strategik dan manajemen pembiayaan dalam suatu kebersamaan yang mengikat. Pernyataan tersebut perlu menjadikan patokan, sehubungan keberhasilan pelaksanaan kebijakan perlu mendapat dukungan dan keterlibatan semua aspek dan mendorong kerjasama dalam pemecahan masalah (Togrol, 2012). Kombinasi tersebut dibentuk dalam sebuah kerangka koherensial yang utuh. Kerangka koherensial tersebut dapat membuka tingkat kepatuhan dan sinergi positif untuk melaksanakan kebijakan karena di dalamnya keterpaduan dari wewenang, rasa percaya diri, kemampuan, keyakinan, kesempatan dan tanggung jawab. Kerangka kerja dalam bentuk koherensial ini sangat bermanpaat, karena koherensi lebih berkaitan dengan sinergi daripada tentang kontradiksi (Gauttier, 2004). Jika kepemimpinan strategik dan manajemen pembiayaan berhasil dalam sebuah kerangka koherensial yang utuh dan padu maka akan menghasilkan sinergi positif dan terhindar dari berbagai kontradiksi. Dengan perkataan lain, kerangka koherensi adalah sebuah tindakan dan perbuatan yang saling berkaitan dan bergerak dalam sebuah kesatuan arah sehingga berdampak bagi sebuah keberhasilan. 
Berkaitan dengan pernyataan tersebut di atas, maka koherensi dari kepemimpinan strategis dan manajemen pembiayaan harus dipahami sebagai kewajiban prosedural yang harus diikuti oleh kesatuan tindakan dari kepala satuan pendidikan, guru-guru, tenaga kependidikan dan para pemangku kepentingan pendidikan lainnya untuk mengkomunikasikan, mengintegrasikan, mensinkronisasikan dan mensimflikasikan berbagai pelaksanaan tugas pokok dan fungsi secara berkesinambungan, berkelanjutan dan memiliki saling ketergantungan diantara para pihak. Dengan kata lain, koherensi menjadi elemen legitimasi dan menciptakan rasa urgensi (tingkat kepentingan) untuk melaksanakan program dan kegiatan sesuai dengan sistem, prosedur dan mekanisme pelaksanaan tugas pokok dan fungsi.

Kerangka koherensial mengembangkan tiga komponen utama yang saling berkaitan yaitu kepercayaan untuk bekerjasama, pengetahuan tentang berbagai masalah-masalah dan kepemimpinan untuk melakukan banyak pekerjaan. Dalam konteks tersebut, pada komponen pertama adalah menciptakan sikap saling percaya, mengembangkan hubungan kerja yang lebih harmonis dan saling menghargai sehingga pada gilirannya dapat menumbuhkan kenyamanan dan suasana kerja yang kondusif. Sedangkan pada komponen kedua meliputi pendayaan, pengkapasitasan dan penguatan kemampuan dalam melaksakannya perannya secara interpersonal, informasional dan pengambil keputusan. Sementara komponen kepemimpinan lebih fokus pada upaya mengarahkan dan menggerakkan yang berhubungan dengan pelaksanaan tugas pokok dan fungsi ke arah pencapaian tujuan pendidikan pada satuan pendidikan. Dimensi yang selanjutnya dapat berkembang dari kerangka koherensial ini adalah nilai-nilai dan etika pelaksanaan tugas pokok dan fungsi, keterbukaan dan pertanggungjawaban yang melekat, peningkatan produktivitas dan kinerja, serta pengendalian dan kontrol yang lebih ketat dalam pelaksanaan tugas pokok dan fungsi. Lebih jauhnya, tingkat kepatuhan dalam melaksanakan peraturan perundang-udangan, penerapan prinsip-prinsip tata pemerintahan yang baik (good governance), penyelesaian wewenang dan fungsi akan lebih mudah terbentuk (Rochaendi, 2018).

Kepastian derajat koherensial terbentuk pada kegiatan peningkatan mutu pembelajaran dan pendidikan, apabila : Pertama, kebijakan peningkatan mutu pendidikan harus dipersepsikan sebagai kebijakan utama dalam merealisasikan visi dan misi satuan pendidikan. Para pelaksana dan pemangku kepentingan pendidikan berkiblat terhadap penyelesaian program dan kegiatan yang searah dan linear dengan visi dan misi yang telah ditetapkan. Kedua, muatan dalam kepemimpinan strategis dan manajemen pembiayaan harus mengakomodasi kebutuhan masing-masing para pelaksana satuan pendidikan dan pemangku kepentingan pendidikan yang senyatanya. Dalam kondisi tersebut, unsur kohesifitas kebutuhan berbanding lurus dengan pelaksanaan tugas pokok dan fungsi. Ketiga, upaya peningkatan mutu pendidikan harus disertai keseragamanan dalam metoda, prosedur dan teknik-teknik secara seimbang dan berkelanjutan sehingga tidak memunculkan multi tafsir dalam implementasinya. Termasuk pula di dalamnya untuk menjaga dan menjamin adanya koordinasi, sinkronisasi, dan kolaburasi yang jelas dan terarah. Keempat, adanya sistem penghargaan yang layak dan mengembangkan nilai-nilai kemanusiaan yang terukur dan komunikatif. Penghargaan yang dikembangkan bisa berupa fasilitasi dalam penyelesaian tugas pokok dan fungsi ataupun dalam bentuk material yang sifatnya natura. Derajat koherensial seperti itu dimungkinkan dapat memperluas sinergi dan produktivitas para pelaksana satuan pendidikan dalam bersikap, bertindak dan berbuat. Iklim yang kuat untuk perubahan berkaitan dengan kejelasan strategi yang optimal. Semngat kepemimpinan dalam kondisi kepercayaan yang tinggi, kolaborasi, dan kepemimpinan yang efektif, mampu untuk berinovasi dan mengambil risiko (Fullan, M. and Quinn, 2016). Dengan perkataan lain, kerangka koherensial ini berperan dan berfungsi mengurangi tingkat kontradiksi, membangun sinergi yang lebih menguntungkan serta menjamin terlaksanakanya kegiatan pelaksanaan tugas dan fungsi menjadi lebih efektif, efisien dan produktif.

Alhasil, dari kombinasi kepemimpinan strategik dan manajemen pembiayaan diharapkan memudahkan dan meringankan dalam upaya peningkatan mutu pendidikan, sehubungan di dalamnya terdapatnya : (a) interaksi yang aktif dan menyeluruh diantara pelaksana satuan pendidikan dengan pemangku kepentingan pendidikan, (b) jalinan komunikasi yang seimbang dan transfaran dalam penyelesaian pelaksanaan tugas pokok dan fungsi, (c) proses penguatan kapasitas dalam tataran sistem, kelembagaan dan sumberdaya manusia, (d) adaptif dan kohesif dengan kebutuhan lingkungan 
masyarakat, dan (e) kolaburatif dan memiliki saling ketergantungan dalam pengimplementasian program dan kegiatan.

\section{SIMPULAN}

Penelitian ini mengajukan argumentasi bahwa peningkatan mutu pendidikan dapat didorong dan dipengaruhi oleh kombinasi kepemimpinan strategik dan manajemen pembiayaan. Argumentasinya diajukan sehubungan sampai saat ini mutu pendidikan tidak menunjukkan perubahan berarti dan bergeser ke arah yang lebih baik, padahal berbagai upaya telah banyak dilakukan dalam mendukung keberhasilan pengelolaan dan penyelenggaraan pendidikan tersebut. Dari hasil penelitian diperoleh sebuah gambaran bahwa faktor kepemimpinan strategis dan manajemen pembiayaan berdampak dan memiliki pengaruh yang kuat terhadap peningkatan mutu pendidikan khususnya di satuan pendidikan SMP. Diperlihatkan bahwa, pelaksanaan kepemimpinan strategik dapat mempengaruhi mutu pendidikan hampir mencapai 43,5 persen, sedangkan pengaruh manajemen pembiayaan terhadap mutu pendidikan hanya mencapai 32,6 persen. Kombinasi diantara keduanya yaitu pelaksanaan kepemimpinan strategik dan manajemen pembiayaan dapat memberikan pengaruh yang signifikan terhadap mutu pendidikan sampai sebesar 60,4 persen. Dengan demikian dapat dikatakan bahwa kepemimpinan strategik dan manajemen pembiayaan memiliki pengaruh yang signifikan terhadap peningkatan mutu pendidikan dasar.

Hal lain yang menjadi perhatian, bahwa peningkatan mutu pendidikan. tidak harus fokus pada penambahan peningkatan prasarana dan sarana pendidikan ataupun diversifikasi dan reformasi kurikulum pembelajaran saja, tetapi harus didukung pula oleh kebersamaan tekad (kepemimpinan strategik) dan mempraktekkan keterbukaan dan mengefisienkan anggaran pendidikan (manajemen pembiayaan) serta mengembangkan kerjasama yang kolaboratif (kerangka koherensial) dalam pelaksanaan tugas pokok dan fungsi dalam penguatan dan pemberdayaan satuan pendidikan. Bersamaan dengan itu mengembangkan intensitas koordinasi dan kohesifitas dengan berbagai pemangku kepentingan pendidikan (stakeholders). Selain itu, tetap membuka diri untuk melaksanakan dialog terbuka dan berkesinambungan diberbagai tingkatan pengelolaan dan penyelenggaraan pendidikan.

\section{DAFTAR RUJUKAN}

Elmore, R. F. (2018). Leadership as the practice of improvement. Paris: OECD.

Fattah, N. (2000). Ekonomi dan Pembiayaan Pendidikan. Bandung: Rosdakarya.

Fullan, M. and Quinn, J. (2016). Coherence: The Right Drivers in Action for Schools, Districts, and Systems. Principals' Council, 4(1), 12-18.

Gauttier, P. (2004). Horizontal coherence and the external competences of the European Union. European Law Journal, 10(1), 23-41., 23-41.

Hamengkubuwono, H. (2021). Manajemen berbasis sekolah di SMP Negeri 1 rejang lebong. Ar-Risalah: Media Keislaman, Pendidikan dan Hukum Islam. 19(2), 254-267.

Hill, C., \& Jones, G. (2013). Theory of Strategy Management (Competitive \& Globalization). South Western: Cangage Learning.

Kemendikbud. (2021). Rencana Strategis Kementerian Pendidikan Dan Kebudayaan Tahun 2020-2024. Jakarta: Jakarta : Kementerian Pendidikan dan Kebudayaan Republik Indonesia.

Nazir, M. (2009). Metode Penelitian. Jakarta: Ghalia Indonesia.

Nopriyani, A., \& Hasanah, E. (2021). Kepemimpinan Kepala Sekolah dalam Meningkatkan Jumlah Siswa Di SMP Muhammadiyah Al Mujahidin Gunungkidul. Syntax Literate; Jurnal Ilmiah Indonesia, 6(2), 558-577.

Pont, B., Nusche, D., \& Moorman, M. (2008). Improving School Leadership (Vol. 1). Paris: OECD.

Rochaendi, E. (2018). Analisis Implementasi Kebijakan Dana Alokasi Khusus (DAK) Bidang Pendidikan Sekolah Dasar. Bandung: UPI.

Sachin, D. S., \& Bansidhar, D. S. (2013). Strategic Leadership: A Need of Today's a Competitive Era. International Journal on Leadership, 1(1), 1-13. 
Sisdiyanto, M. S. (2021). Pengaruh Transformational Leadership, Reward Dan Work Engagement Terhadap Perilaku Kerja Pegawai Direktorat Jenderal Pendidikan Islam Kementerian Agama RI. Jurnal Karya Abdi Masyarakat, 5((1)), 17-28.

Stoll, L., Bolam, R., Mc. Mahon, A., \& Wallace, M. (2006). Professional Learning Communities: A Review of the Literature. Journal of Educational Change, 7, 221-258.

Sugiyono. (2013). Metode Penelitian Kuantitatif, Kualitatif dan Kombinasi (Mixed Methods). Bandung: alfabeta.

The Wallace Foundation. (2012). The School Principal As Leader: Guiding Schools To Better Teaching And Learning. New York: Springer.

Togrol, A. Y. (2012). Studies of the Turkish form of the Test for Creative Thinking-Drawing Production. Creative Education, 03(08), 1326-1331. https://doi.org/10.4236/ce.2012.38194

UNDP. (2019). Human Development Report 2019, Beyond income, beyond averages, beyond today: Inequalities in human development in the 21st century. New York.

Wahyudi, A., Liliasari, S., Supriyanti, F. M. T., \& Nahadi. (2019). The Development and validation of critical and creative thinking skills test in enzyme for undergraduated chemistry students. Unnes Science Education Journal, 8(1), 76-83. 